\title{
Változásmenedzsment alapjai
}

\section{Grounds of Changemanagement}

\author{
Zs. GÁL \\ Debreceni Egyetem, Ihrig Károly Gazdálkodás- és Szervezéstudományok Doktori Iskola \\ zsuzsa.gal1218@gmail.com
}

Absztrakt. A 21. századi szervezetekben állandósult a változás. A változásmenedzsment olyan terület, amely az irányított, tudatos változtatásokkal foglalkozik, bár spontán változások is végbe mennek egy szervezet életében. $A$ változással már az 1970-es évektől kezdve foglalkoznak a társadalomtudományban, és egyre nagyobb jelentőséggel bír, hisz sok esetben a szervezetek életében a változáshoz való alkalmazkodás a túlélés feltétele. A cikkben bemutatom a változásmenedzsment fejlődését, elméleteit, és a napjainkban legfontosabb kérdéseket.

Abstract. Organisations of the 21st century exist in a permanent change. Change management in business management deals with the analysis of directed and planned changes. However, it does not consider spontaneous changes. Change has been addressed in social science since the 1970s and is of growing importance. As in many cases adapting to the change is crucial for the organisations to survive. With the changeThese spontaneous changes are chaotic processes that are carried out without control. In this paper I present the evolution of changemanagement, and the most important questions of changes.

\section{Bevezetés}

A változás mindenki számára ismerős jelenség, hiszen az élet minden területén találkozunk vele. Észrevétlenül reagálunk a minket érő külső környezet módosulására. Számtalan hatással találkozunk, amely mind megkívánja az egyéntől, hogy alkalmazkodjon. A szervezeteket is érik folyamatosan változást generáló események: módosulhat a jogszabályi háttér, hirtelen drasztikusan megváltozhat a megrendelések száma, növekedhet a fluktuáció és még számos olyan esemény következhet be, amelyekre a lehető legrövidebb idő alatt hatékonyan szükséges reagálniuk. Mondhatjuk azt is, hogy a szervezetek számára az őket érő változásokra való reagálás a fennmaradás feltétele. Minden esetben igaz az, hogy a változások bizonytalanságot okoznak, és emiatt feszültséget generálnak. Azonban a változás a szervezeti lét mindennapos, magától értetődő jelensége.

Célom, hogy bemutassam a változás alapvető összefüggéseit, elméleti hátterét, valamint a változásmenedzsment jelenlegi kérdéseit. Hiszen ez egy olyan terület minden szervezet életében, amit nem tud kikerülni, vagy megelőzni. Változások voltak, vannak és lesznek is. A szervezet tagjainak célja pedig az, hogy kézben tartsa, menedzselje, szükség esetén pedig akár generálja és menedzselje a változásokat. 


\section{A változás}

Az egyik talán legismertebb változáselméleti modell a Lewin-féle erőtér modell (1972) [1], amelyen keresztül a változás leírható. Az elmélet szerint egyetlen entitás (egyén, csoport, szervezet, társadalom) sincs légüres térben: egy ráható mező veszi körül, amelynek sajátos jellemzői vannak. A mezőelmélet további fontos jellemzője még, hogy konstruktív (egyik esetből le lehet vezetni a másikat), dinamikus (a viselkedés mögötti erőket térképezi fel), megközelítése pszichológiai, nem pszichikai, a szituációt mint egészet figyeli és ebben keresi a részinformációkat, a viselkedés a mező függvénye (ha a mező megváltozik, a viselkedés is meg fog változni) és matematikailag reprezentálható (topológiai elrendezés, kvantitatív elemzés lehetősége). Ebben a megközelítésben a változás azt jelenti, hogy egy rendszer jellemzői, ahogyan haladunk előre az időben, valamely paraméterei mentén mást mutatnak, mint korábban [2]. Továbbgondolva a Lewin nevéhez füződő elméletet, a változás folyamatát, állapotait, és azok jellemzőit egy modellbe foglalható össze (1.ábra).

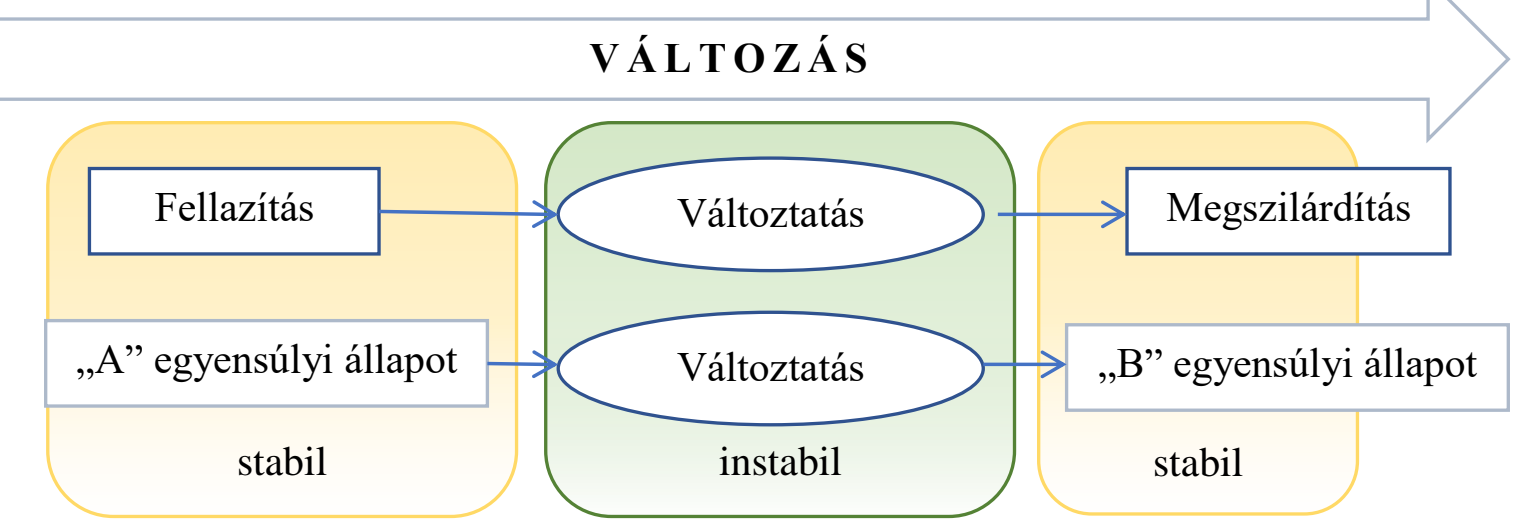

1. ábra. A változás folyamatának szakaszai

Forrás: [1] alapján saját szerkesztés

$\mathrm{Az}$ alapelmélet szerint a stabil, egyensúlyi állapotra ható változást akadályozó és generáló tényezők egyensúlya felborul, amely által a korábbi stabil állapot megszűnik és instabillá válik a szervezet. Szükségessé válik az alkalmazkodás, azaz megváltoztatni a korábbi állapotot, hogy a kialakult új helyzetben képes legyen fennmaradni a szervezet.

A szakirodalomban a változási folyamatot kiegészítik az egyensúlyi állapottal, a kimozdítással és az ezt követő egyensúlyi állapottal, ahogyan $a z$ 1. ábrán is látható. A változtatás itt is középen helyezkedik el, az egyensúlyi állapotból való kibillenést követően. Az is látható, hogy amennyiben a stabilitását akarjuk megfogalmazni a különböző szakaszoknak, akkor a fellazítás, vagy „A” egyensúlyi állapotot, és a megszilárdítást „B” egyensúlyi állapotot stabilnak, míg a változtatást instabilnak nevezhetjük. Tehát, amikor egy szervezet változásmenedzseléséről beszélünk, akkor abba már a fellazítást is, valamint az instabil, egyensúlyi állapotból kizökkent állapotot és a megszilárdítást, vagy konszolidálás szakaszát is beleértjük. Nem csupán a változtatáskor megvalósuló intézkedések, hanem a teljes folyamat idetartozik. Bár nem új kérdés, mégis szükséges a három lépéses változási modell kapcsán egy újabb problémát is megemlíteni: Napjainkban a rendkívül gyors változások, amelyek a környezetben végbe mennek, már nem feltétlenül képesek a szervezet számára elegendő időt biztosítani arra, hogy ez a stabil, befejező állapot létrejöhessen. Ennek értelmében nem minden esetben beszélhetünk a befejező állapot 
eléréséről, a szervezetek a permanens változás mellett az állandó alkalmazkodás folyamatában vannak: stabil állapotról alig beszélhetünk, a szervezetekre leginkább az állandó instabilitás jellemző.

Ebben az állandósult instabilitásban kell megtalálniuk azt a vékony vonalat, ahol egyensúlyi állapotot ugyan nem, vagy csak rövid időre képesek létrehozni, de egyensúlyozni tudnak. Ehhez pedig elengedhetetlenné válik a változásokra adott tudatos, irányított reakció, amelynek a változásmenedzsment ad keretet.

\section{Változásmenedzsment}

A változással kapcsolatos elméletek a Lewin három lépéses modelljében gyökereznek. Ez a három lépés egy egységet képez, hiszen egymástól elválaszthatatlan folyamatokról van szó. [3] átvizsgált 200 változás-menedzsmenttel foglalkozó cikket, annak érdekében, hogy megválaszolja, mi hajtja a változásokat. Vizsgálatában négy nagyobb csoportot tudott elkülöníteni: a teleologikus motort, életciklus motort, dialektikus motort és az evolúciós motort (in [2]). Eszerint a teleologikus motor a célok meghatározásán, megvalósításán, értékelésén és további módosításán keresztül hajtja a változást. Az életciklus motor alapján a változás olyan folyamat, ami előre meghatározott állomásokon keresztül megy végbe. A dialektikus motor megközelítése alapján a változások a szervezetben lévő egységek egymás közötti konfliktusainak eredményeként jönnek létre. Az evolúciós motor elméletei szerint pedig a fő fókusz a környezeti feltételek nyomására generált szervezeti reakciókon van.

A változásmenedzsment elméleti megközelítései számos módon csoportosíthatók, azonban fel kell tennünk a kérdést, hogy mi is a célja a változásnak és a változtatásnak?

A változás és a változtatás között szükséges különbséget tennünk. Hiszen a változtatás egy adott pillanatban következik be, eredményeként egy új állapot kerül bevezetésre. A változás azonban egy folyamat, amelynek eredményeként új, vagy újszerű alternatívák kerülnek a szervezet struktúrájába, magatartásába, kultúrájába, szemléletmódjába. A szervezeti változtatások alatt minden esetben irányított változtatásokat kell érteni, hisz maga a szervezeti változtatás kifejezés már önmagában is utal a vezetés aktív részvételére [4]. Ezzel a kérdéssel kapcsolatban Molnár [5] is úgy vélekedik, hogy a köznapi nyelvben sokszor hibásan használjuk a változás szót. Doktori értekezésében már a változtatásmenedzsment kifejezést használja. Molnár [5] az irányíthatóság szerint tesz különbséget a változás és a változtatás között. A változás általunk nem irányítható módon történik, a legfontosabb, hogy megfelelően válaszoljunk rá. Ezzel szemben a változtatás során a történést mi magunk irányítjuk, és tudatában vagyunk annak, hogy mit, hogyan és milyen eredmény elérése érdekében teszünk. Molnár et al. [6] kiemelte, hogy ezzel a különbséggel a szervezeteknek kiemelkedően fontos tisztában lenniük a gyakorlatban való alkalmazáshoz. Gulyás [7] szerint a változásmenedzsment a szervezet korábbi állapotából új állapotába való átvezetését jelenti. A változások megfelelő kezeléséhez emellett mindenképpen szükséges a szervezet vezetőinek vizsgálata. Más szerző megkülönböztet tervszerű beavatkozásokat és spontán változásokat [1] A tervszerű beavatkozás során előre eltervezett, tudatos tevékenységről van szó, amelynek következeménye kiszámítható. A spontán változás azonban olyan esetekben fordulhat elő, amikor a helyzetek előre nem láthatók, előzetes mérlegelésre, tervezésre nincs lehetőség. A spontán beavatkozás olyan esetekben fordulhat elő, amikor a helyzetek előre nem láthatóak. Ebben a megközelítésben minden olyan kialakult szituáció, amely beavatkozást igényel, más és más jellemzőkkel bír, és eltérő beavatkozásokkal oldható meg. 
Véleményem szerint is szükséges a változás és a változtatás között különbséget tenni. A szakirodalom eredeti nyelven nem feltétlenül alkalmazza hibásan ezeket a kifejezéseket, sokkal inkább a magyar fordítás és a magyar nyelvbe való átültetés nem egyértelmű. A következő fejezetekben tehát a szakirodalmi elnevezésektől és magyar fordításoktól függetlenül, azok értelmezése után az ismertetetteknek megfelelően fogom használni a változás és a változtatás szavakat.

\subsection{A változtatás lehetséges csoportosításai}

A dinamikus és heterogén társadalmi és gazdasági környezet hatására a 21. századra jellemző állandó változás ma már elfogadott jelenség, amely az élet minden területét áthatja. Ennek következtében stabilitásról szinte soha nem beszélhetünk, minden folyamatosan változik, napról napra szükségessé válik alkalmazkodni a kialakult új, megváltozott körülményekhez, legyen szó jogszabályi környezetről, fogyasztói szokásokról, piaci jelenségekről, vagy globális folyamatok okozta változásról. A szervezetek reagálása a változó környezetre, amelynek hatására struktúrában, magatartásban, szemléletmódban módosulások lépnek életbe, nevezzük változtatásnak [4]. A környezeti módosulásokra adott reakciókat, azaz a változtatást megkülönböztethetjük több szempontból is. A szakirodalom olyan csoportosításokat tartalmaz, amelyeket például a változás üteme, mértéke, módja, az általa kiváltott módosítások mértéke alapján képeznek.

A változtatások lehetnek elsőfokúak, és másodfokúak. Elsőfokú (morfostatikus) változás, változtatás során az adott rendszer változatlan marad, míg a másodfokú (morfogenetikus) változtatás esetén a rendszer megváltozik (Levy - Merry, 1986 in [8]. Úgy is fogalmazhatunk, hogy elsőfokú változás esetén a régi rendszer keretein belül történik változtatás, míg a másodfokú változás esetén kilépünk a régi rendszer kereteiből, és megváltoztatjuk azt. A változtatás bizonyos szakirodalom szerint ([9]; [10]) a változtatás a szervezet hosszú stabilitási szakaszainak és a forradalmi változások rövid szakaszainak váltakozása (megszakított egyensúlyi paradigma).

További megkülönböztetési szempont a változtatás mértéke szerinti különválasztás. Ez alapján beszélhetünk inkrementális (evolutív) és radikális (revolutív) változtatásokról. Az olyan szervezeti átalakítások során, ahol az érintett részleg kapcsolatban áll valamennyi részleggel (például informatikai), úgy érhető el jó eredmény, ha a változtatás a szervezet valamennyi folyamatát, dolgozóját, egységét magába foglalja (radikális változtatás szükséges), ellenkező esetben elégséges az inkrementális változtatás is [11]. Az inkrementális és radikális változások összevetését Dobák [12] alapján az 1.táblázatban szemléltetem.

\begin{tabular}{|c|c|c|}
\hline Inkrementális változás & Szempontok & Radikális változás \\
\hline $\begin{array}{l}\text { Egy, vagy néhány lényeges szervezeti } \\
\text { jellemző változik }\end{array}$ & $\begin{array}{l}\text { A változás } \\
\text { terjedelme }\end{array}$ & $\begin{array}{l}\text { Számos, vagy az összes lényeges szervezeti } \\
\text { tényező változik }\end{array}$ \\
\hline $\begin{array}{l}\text { A megváltozó szervezeti jellemzők } \\
\text { kismértékű módosulása }\end{array}$ & $\begin{array}{l}\text { A változás } \\
\text { mértéke }\end{array}$ & A szervezeti jellemzők nagymértékű változása \\
\hline $\begin{array}{c}\text { A szervezet egy vagy néhány } \\
\text { hierarchikus szintjét érintő változások }\end{array}$ & $\begin{array}{l}\text { A változás } \\
\text { szintje }\end{array}$ & $\begin{array}{l}\text { A szervezet minden hierarchikus szintjén ható } \\
\text { változások }\end{array}$ \\
\hline $\begin{array}{l}\text { Lépésről lépésre bekövetkező, kevésbé } \\
\text { látványos változások }\end{array}$ & $\begin{array}{l}\text { A változás } \\
\text { módja }\end{array}$ & $\begin{array}{l}\text { Nagyobb, látványos „ugrások” révén } \\
\text { bekövetkező változások }\end{array}$ \\
\hline $\begin{array}{l}\text { Viszonylag lassan bekövetkező } \\
\text { változások }\end{array}$ & $\begin{array}{l}\text { A változás } \\
\text { sebessége }\end{array}$ & $\begin{array}{l}\text { A változások viszonylag gyorsan következnek } \\
\text { be }\end{array}$ \\
\hline
\end{tabular}




\begin{tabular}{|c|c|c|}
\hline $\begin{array}{c}\text { A szervezet külső alkalmazkodásának } \\
\text { elömozdítása és/vagy a szervezeti } \\
\text { alrendszerek, struktúrák és } \\
\text { folyamatok belső illeszkedésének } \\
\text { továbbfejlesztése }\end{array}$ & $\begin{array}{c}\text { A változás } \\
\text { alapvető } \\
\text { célja }\end{array}$ & $\begin{array}{c}\text { A szervezet külső alkalmazkodásának } \\
\text { előmozdítása és/vagy a szervezeti } \\
\text { alrendszerek, struktúrák és folyamatok új } \\
\text { konfigurációjának létrehozása }\end{array}$ \\
\hline $\begin{array}{c}\text { Alsóbb szintű vezetők vagy a felső } \\
\text { vezetés irányítja }\end{array}$ & $\begin{array}{c}\text { A változás } \\
\text { irányítása }\end{array}$ & $\begin{array}{c}\text { A felső vezetés irányítja „mindkettő } \\
\text { menedzselt és irányított. }\end{array}$ \\
\hline
\end{tabular}

1. táblázat: Inkrementális és radikális változások összevetése

Forrás: Dobák [12] alapján saját szerkesztés (2019)

További elméletek is találhatóak a radikális és inkrementális változtatások megfogalmazására, így például Deák [13] szerint a változásra adott inkrementális válaszok apró változtatásokkal, de folyamatosan mennek végbe, a radikális válaszokat azonban hirtelen, ugrásszerűen hajtják végre. Ez a változtatási csoportosítás erősen hasonlít az első- és másodfokú változtatások tartalmára.

Watson (1993) ütemezési csoportosítása ettől minimálisan eltérő. Háromféle ütemezést különböztet meg: „big bang”-et, a próbát (pilot) és a párhuzamos futtatást. Itt az első két esetben a régi rendszert egyszerre, teljes egészében váltja fel az új rendszer, a próba ütemezés során kis léptékben és fokozatosan kerül bevezetésre az új rendszer, míg a párhuzamos futtatás esetén a régi rendszer addig működik az új rendszerrel párhuzamosan, míg a régi rendszer biztonsággal elhagyhatóvá válik (biztonságos) [11].

A változtatásokat megkülönböztethetjük olyan szempontból is, hogy azok gazdasági értékekre, vagy a szervezeti kapacitásokra helyezik a hangsúlyt. Beer - Nohria [14] értelmezése szerint így elkülöníthetjük a változtatásokat E-elmélet (gazdasági értékek) és 0-elmélet (szervezeti kapacitások) szerint. Másképp a gazdasági alapokra épített változtatásokat nevezhetjük „kemény” megközelítésnek, míg a szervezeti kapacitásokon alapuló változtatásokat „puha” megközelítésnek. Alapvető különbségek vannak a célok kijelölésében, a vezetés irányában, a fókuszban, folyamatban, jutalmazási rendszerben és a tanácsadók alkalmazásában is, azonban a két elmélet ( $\mathrm{E}$ és 0) kombinálható is.

A változtatás szintjei között különbségek észlelhetők, azonban ezek a szintek nem önmagukért fontosak, sokkal inkább a köztük lévő kölcsönhatás miatt (Deuringer, 2000 in [11]). Deuringer csoportosításában különbséget tesz a szervezetben és a stratégiában való változtatás és az elméleti és tényszerü változtatások között is.

\begin{tabular}{|c|c|c|c|}
\hline & $\begin{array}{c}\text { Változtatás a } \\
\text { szervezetben } \\
\text { (állapot) }\end{array}$ & $\begin{array}{c}\text { Változtatás a } \\
\text { stratégiában (irány) }\end{array}$ & A változtatás leírása \\
\hline $\begin{array}{c}\text { inkább } \\
\text { elméleti } \\
\text { (gondolat) }\end{array}$ & kultúra, struktúra & vízió, pozíciók & $\begin{array}{c}\text { Átgondolás/átfogalmazás, } \\
\text { átstrukturálás/átcsoportosítás/ } \\
\text { átkonfigurálás }\end{array}$ \\
\hline $\begin{array}{c}\text { inkább } \\
\text { tényszerű } \\
\text { (cselekedet) }\end{array}$ & rendszerek, emberek & programok, eszközök & $\begin{array}{c}\text { Átdolgozás/átprogramozás, } \\
\text { újraformálás/csökkentés }\end{array}$ \\
\hline
\end{tabular}

2. táblázat: A szervezeti változtatás Deuringer (2000) szerinti csoportositása

Forrás: Farkas [11] alapján saját szerkesztés (2017) 
A 2. táblázat arra ad választ, hogy a környezeti változásokra a szervezetek hogyan, milyen változtatásokkal reagálhatnak, vagy reagálnak (például: kultúra váltás, struktúra változtatás, rendszerek, emberek változtatása). A szervezetben vagy stratégiában végbemenő változtatás valamilyen külső, vagy belső környezeti feltétel módosulása miatt megy végbe (fordításban a szerző is a változás kifejezést használta).

A változtatások bevezetésének szakaszában is elkülöníthetünk gyors és lassú változásokat, a stratégia megfelelő kiválasztásához Kotter és Schlesinger [15] szerint négy tényezőt kell figyelembe venni:

- Az ellenállás előre jelezhető mértéke és formái,

- a kezdeményező és az ellenállók pozíciói, különös tekintettel hatalmukra,

- kik azok a személyek, akiknél a változás megtervezéséhez szükséges lényeges információk vannak, és akiknek erőfeszítéseire számítunk a változás megvalósítása során,

- a változás tétje.

Ahogyan azt ebben a fejezetben ismertettem, számos csoportosítás létezik, amely a változtatások csoportosítását hivatott kifejezni. A leírt csoportosításokat a 3. táblázatban ábrázolom összefoglalóan.

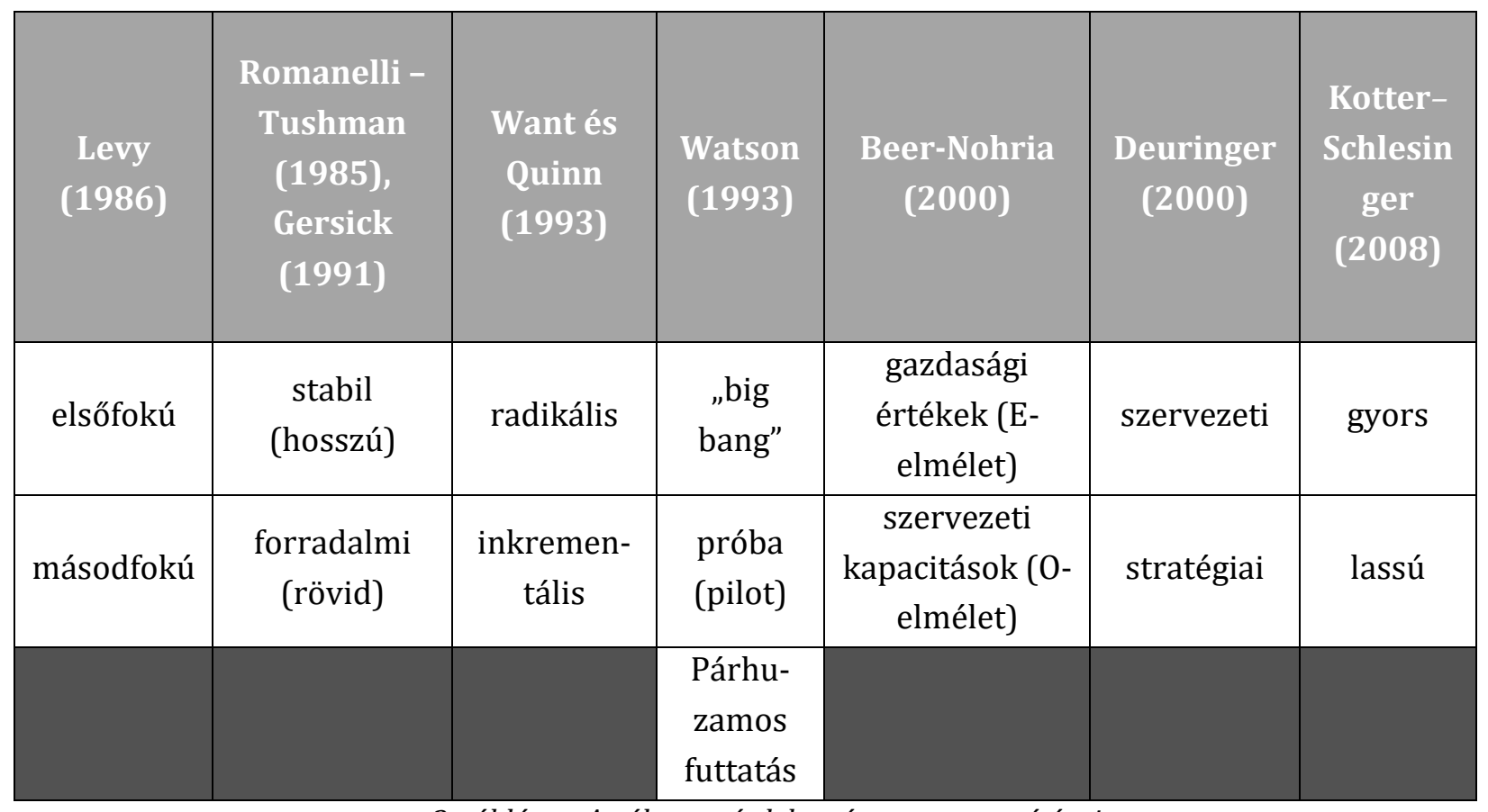

3. táblázat: A változtatás lehetséges csoportosításai

Forrás: Saját szerkesztés (2017)

Az összefoglaló tábla alapján láthatjuk, hogy a csoportosítás szempontjai eltérőek a különböző szakirodalmakban. Az azonban egyértelmű, hogy ezek a felosztások három nagyobb szempont köré csoportosulnak. Az egyik szempont a változtatás mértéke (nagyobb, vagy kisebb változtatásról), amelyet Want - Quinn (1993), és Levy (1986) is felhasznált (11). A másik szempont a szervezetre gyakorolt hatás, amely Beer- Noohria (2000) [14] a és Deuringer (2000) által használt csoportosításban lelhető fel [11]. A harmadik szempont az időtényező, amelyet Gersick (1991) (10), Romanell - Tushman (1985) [9] és a Kotter-Schlesinger (2008) [15] szerzők is alkalmaztak. Csoportosításukban a hosszú és rövid ideig tartó, valamint a gyors és lassú változtatások szerepelnek. Az idő változtatásban betöltött szerepéről a Bácsné (2009) által elvégzett vizsgálatok is kimutatták, hogy mind a tartalmi, mind a folyamat feladatok esetében fontos az időtényező [16]. 
A 2. táblázatban szereplő elméletek, modellek időbeliségét tekintve azt láthatjuk, hogy a korai időszakban (a 90-es évek elején) a változtatás mértéke volt fontosabb. Gersick (1991) és Romanell Tushman (1994) szerzőknél megjelent az időtényező szerepe, de nem ez volt a jellemző. Ezt a mentalitást az ezredforduló környékén váltotta fel a szervezeti és gazdasági szerepek fontossága. Napjainkban, ahogyan Kotter - Schlesinger (2009) modellje és a Bácsné (2009) kutatásai is mutatják, az idő szerepe vált kulcsfontosságúvá. Az általam folytatott vizsgálatban a Want - Quinn (1993) féle megközelítést alkalmaztam.

\subsection{A változtatást generáló tényezők}

A szervezeti változásokat külső és belső okok is kiválthatják. Amennyiben a korábban ismertetett jelentésbeli különbségekhez nyúlunk vissza, akkor azt mondhatjuk, hogy a változás szinte minden esetben a külső környezeti feltételek módosulása. Ebben az értelemben minden belső változást változtatásként kell értékelnünk, hiszen az a külső környezeti változásokra adott tudatos, tervezett válaszreakció. Molnár (2015) [5] is ezt támasztja alá, hiszen a változást úgy értékeli, mint tőlünk függetlenül végbemenő folyamat, amire nem vagyunk képesek hatni, míg a változtatás során egy irányított tevékenységről beszélünk. Említést tesz olyan változásról, amelyre képesek vagyunk hatni, mint például egy új termék bevezetése, vagy a felvásárlások. Az ismertetett szakirodalmak alapján azonban ezzel nem értek egyet, hiszen az új termék bevezetésekor a gyártó szervezet változtatást hajt végre (például gyártástervezésben, ütemezésben, fejlesztésben, marketingtevékenységben, értékesítésben), és a versenytársak számára okoz ezzel változást a piaci környezetben, nem saját magának. Az új termék bevezetése a fogalmak értelmében tervezett, tudatos tevékenység eredménye, ez pedig nem más, mint változtatás. A felvásárlás során is hasonló következtetésre juthatunk, hiszen a környezeti feltételek módosulnak (valamilyen ok miatt érdemessé válik felvásárolni az adott terméket, ingatlant, egyéb szolgáltatást), amelyre a szervezet tudatosan készül fel és tervszerűen hajtja végre.

A permanens változások századában nem véletlen, hogy mind a hazai, mind a nemzetközi piacon számos tényezővel kell megküzdenie a szervezeteknek [17]. Emellett kutatási eredmények is igazolják, hogy a változásokat leggyakrabban kiváltó tényezők a külső környezetből fakadnak, így például a piaci igény változása, valamint a piaci verseny erősödése [18].

Véleményem szerint a változtatást generáló tényezők között kizárólag külső tényezők szerepelhetnek, mivel a változtatás minden esetben valamilyen környezeti feltétel módosulására adott reakció, amely önmagában nem belső tényezőkből ered, hanem külső indíttatású. Az adott környezetben tevékenykedő szervezet nem képes hatást gyakorolni ezekre, csak reagálni képes. Farkas [11] tesz említést a Porterféle öttényezős modellről, amelyben valóban kizárólag külső környezeti tényezők szerepelnek, amelyek változást okoznak és változtatásokat képesek generálni. A külső kiváltó ok érkezhet a szervezet makro környezetéből, azaz a politikai, gazdasági, társadalmi-kulturális vagy technológiai környezetből [19]. A makro környezet vizsgálatához a PEST analízisben használt tényezők figyelembevétele lehetséges. Az analízisben figyelembe vesszük a politikai, jogi, gazdasági, társadalmi és technológiai folyamatok alakulását. Azonban a változást kiváltó okok a mikrokörnyezetben is jelentkezhetnek. Porter öttényezős modelljének megfelelően változhat a szervezet beszállítóival szembeni alkupozíciója, új szereplő, vagy helyettesítő termék/szolgáltatás jelenhet meg a piacon, illetve változhat a versenytársak közötti verseny jellege, természete is (2. ábra). Mindkét környezetben bekövetkező változások jelentős hatással lehetnek a vállalkozás működésére és késztethetik azt reagálásra. 
A változtatást generáló tényezők igen széleskörűek, amelyek valóban folyamatosan módosulnak. A szervezeteket egyaránt érinti a mikrokörnyezetében (szállítóknál, vevőknél, helyettesítő termékeknél, versenytársaknál) és a makro környezetben (jogi szabályozásban, politikai szabályozásokban) bekövetkező változás is. Vannak olyan módszerek, amelyekkel fel lehet ezekre készülni. A változásokra való felkészülés kapcsán megkülönböztet a szakirodalom megelőző és reaktív változtatásokat is. A megelőző típusú változásoknál a környezeti hatás jelentkezését meg nem várva következik be a szervezet részéről a változtatásban megjelenő válasz (finomhangolás, vagy irányváltás), míg a reaktív (reagáló) változtatás esetén a környezeti hatás jelentkezésére következik be válaszreakció a szervezettől (alkalmazkodás, vagy helyreállítás) [11]. Ahogyan az látható, a szakirodalom számos megközelítésbe helyezi a változásokat, annak értelmében is, külső vagy belső irányultságúak azok a hatások, amelyek új megközelítést igényelnek a szervezetektől. A változtatások formáját elkülöníti több szerző is és ez alapján alapvető különbségeket is tesz abban, hogy milyen módon reagál a szervezet az őt érő változásra.

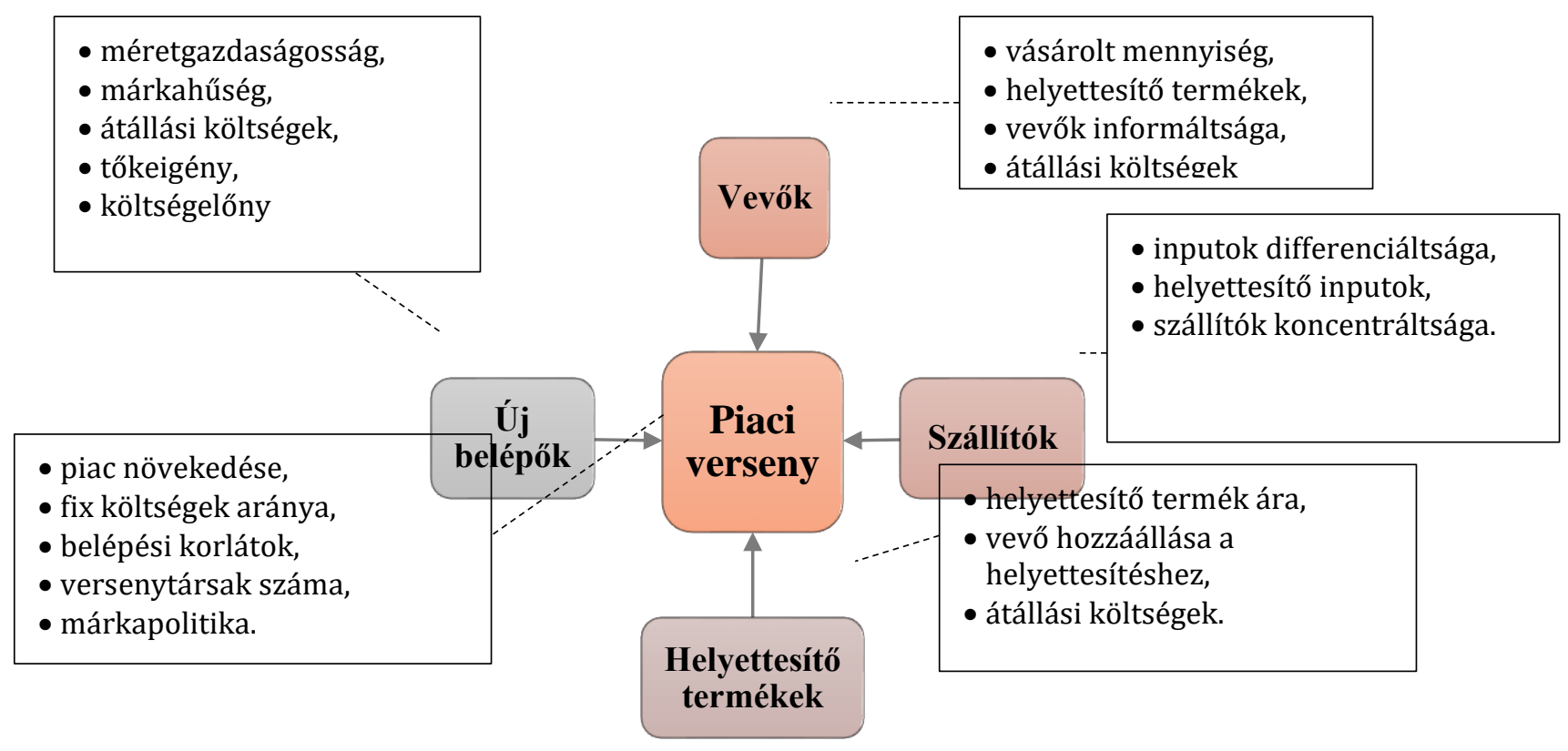

2. ábra: Porter-féle öttényezős modell

Forrás: Porter, 2006 [20] alapján saját szerkesztés (2017)

\section{Változtatásmenedzsment és módszerei}

A változásmenedzsment kialakulása a 19. századra tehető. 1833-ban Taylor munkássága alapozta meg a változtatások tervezett végrehajtásának szükségességét, azonban a szervezetek emberi aspektusa teljesen háttérbe szorult a változások folyamatának megvalósulásában. Az előrelépést ebben Mayo 1927-ben végzett vizsgálatai jelentették, melynek eredményeként a személyes kapcsolatok fontossága is szerepet kapott az eredményesség növelésében [11]. 
A változásmenedzsment szemléletmódja és módszertana az évtizedek alatt sokrétű átalakuláson esett át [11]. A 20. század második felétől az eddigiektől eltérő megközelítést alkalmaztak a változtatásokra, amikor bevezették a már korábban részletezett másodfokú változtatás fogalmát. Erről azonban nem csupán a változtatásmenedzsment kapcsán beszélhetünk, hanem a pszichológia szakterületén is alkalmazzák e fogalmakat [20]. A vezetés mindkét fajta változtatáshoz szükséges, hiszen mindkettőt emberekkel végezzük, a különbség csupán az, hogy a másodfokú változtatásokban nagyobb szerepe van az egyénnek, mert ezt sokkal nehezebben fogadják be (Kotter, 1990 in: [21]). A változtatásmenedzsment Mink et al. (1993) szerint a morfogenetikus változtatások menedzselésével foglalkozó menedzsment szakterület (in [21]). Ebben az értelemben a változtatásmenedzsment kizárólag azokkal a változtatásokkal foglakozik, amely a szervezet egészét érinti.

A távol-keleti gazdaság felemelkedése és megerősödése a szervezetek „lágy” tényezői és azok minél hatékonyabb kezelésének tudható be (Collins, 2003 in: [11]) A változások üzleti folyamatszemléletű megközelítésének és a szervezetek emberi tényezőinek prioritását hangsúlyozó elméletek összevonásából születtek meg az úfajta, integrált szemléletmódot tükröző modellek. Az integrált változásmenedzsment- modellek kiváló példájának tekinthetjük a Balanced Scorecard modellt, amely négy különböző szemléletmódot egyesít egy közös rendszerben. A BSC módszert 1990-ben publikálta David Norton és Robert Kaplan [22] amely egy újfajta megközelítést tükrözött. A módszer a szervezeti teljesítmény mérését és tervezését innovatív módon közelítette meg [23]. A BSC módszer komplexitása mellett azonban nem mehetünk el a napjainkban egyre fontosabbá váló tanulás és a vezetői tudás kérdésköre mellett. Juhász [24] említést tesz a vezető meglévő tudásáról is, amely egyaránt lehet explicit, és tacit. Állítása szerint a változásokhoz olyan szervezetek képesek alkalmazkodni, akik a változásokból képesek tanulni, a már megszerzett tudásukat menedzselni és fejleszteni.

Különösképpen az utóbbi miatt válik fontossá a vezetői tudás vizsgálata mellett a vezető személyiségének feltérképezése. Azon kulcsjellemzők megállapítása, amelyek elengedhetetlenek a változásokra történő megfelelő reagálás miatt, amelyen a szervezet jövője is múlhat.

Alapvető összefüggés, hogy a változásokat külső-belső folyamatok generálják, de csak a szervezetek vezetői menedzselhetik.

\section{Összefoglalás}

A szervezetek életét napjainkban alapvetően áthatja a változásra való reagálás kényszere. Egyre nagyobb jelentőséggel bír az, hogy milyen gyorsan, és milyen minőségben képesek alkalmazkodnia környezeti feltételek módosulásához. Számos olyan változás érheti egy szervezetet, amely érkezhet külső környezetből, de kialakulhat a szervezeten belül is. Az, hogy a változásra adott válasz hogyan valósul meg egy szervezet életében, számos tényező által lehatárolt. A cikkben bemutatott elméletek mindegyike alkalmas lehet arra, hogy adott tényező mentén értékeljünk egy sikeresen végrehajtott változtatást. Azonban az elméleti háttér ismertetése során arra is fény derül, hogy az időtényező szerepe egyre kiemelkedőbbé válik. A szervezetek túlélésében már nem csak az játszik szerepet, hogy hogyan és milyen minőségben reagálnak a változásra, hanem az is, hogy milyen gyorsan képesek azt megtenni. 


\section{Szakirodalmi jegyzék}

[1] Berde Cs. (2015): Vezetési feladatok In: Bácsné B. É. - Berde Cs. - Dajnoki K. (szerk.) (2015): A vezetés alapjai, Debreceni Egyetem, ISSN 2416-1969, ISBN 978-615- 80290-25 p.5-28.

[2] Poór J. (2004): Menedzsment-tanácsadási kézikönyv, Akadémia Kiadó Zrt. pp.115-120

[3] V. De Ven - Poole. "Explaining Change and Development in Organizations." Academy of Management Review 20 no. 3 (1995): 510- 540.

[4] Berde Cs. - Dajnoki K. - Dienesné K. E. - Gályász J. - Juhász Cs. - Szabados Gy. (2003): Vezetéselméleti ismeretek, Debrecen, Debreceni Campus Kht. ISBN 963206642 1, p.71-76

[5] Molnár I. (2015): Változtatásmenedzsment a hazai gyakorlatban, doktori értekezés, Nyugat-magyarországi Egyetem, Sopron, p.9.

[6] Molnár I. - Léder L. - Kielkopf E. - Loós T. - Baksi Zs. - Gurabi A. (2017): Kihívások és tanulságok a menedzsment területén, Nemzetközi Tudományos Konferencia, kerekasztal beszélgetés, 2017. március 9-10.

[7] Gulyás L. (szerk.) (2008): A vezetéstudomány alapjai. JATEPress. Szeged. 2008. p.107.

[8] Pataki B. (2014) - A változásmenedzsment, oktatási segédlet, Budapesti Műszaki- és Gazdaságtudományi Egyetem, p.7-9

[9] Romanelli, E-Tushman, E. L. (1985): Organizational evolution: A metamorphosis model of convergence and reorganization. in: Burke, W. W.- Dale, G.L. - Waymire, J. P. (2009): Organization Change: A Comprehensive Reader. John Wiley \& Sons Inc., San Fransisco, p.174-225

[10] Gersick, C. J. G. (1991): Revolutionary Changes Theories: A multilevel Exploration of the Punctuated Equilibrium Paradigm, Academy of Management Review

[11] Farkas F. (2013): A változásmenedzsment elmélete és gyakorlata, Budapest, Akadémia Kiadó, ISBN 9789630594325 HU ISSN 2061-6430, p.17-

[12] Dobák M. (2008): Szervezeti formák és vezetés, Budapest, Akadémia Kiadó, ISBN 9769630583406

[13] Deák Cs. (2000): A szervezeti változás napjaink magyar vállalatainál egy kísérleti felmérés alapján in: Észak-Kelet Magyarország, Gazdaság - Kultúra - Tudomány, Társadalompolitikai folyóirat, 2000. 10. szám, pp. 23-25.

[14] Beer M. - Nohria N. (2000): Cracking the code of change in: Harvard Business Review, On Change HBR's 10 must reads, pp.85-96. http://ceewl.ca/12599-PDF-ENG.PDF\#page=89

[15] Kotter J.P. - Schlesinger L.A. (2008): Choosing strategies for Change in: Harvard Business Review (2008. 07-08.), ISSN 0017-8012 p.130-139. https://hbr.org/archive-toc/BR0807

[16] Bácsné B.É. (2009): Az időtényezô szerepe a vezetô és a szervezet működésének eredményességében, doktori értekezés, Debreceni Egyetem, Debrecen p. 85-93. 
[17] Bencsik A. - Juhász T. (2012): Chance of Succes at Hungarian Small and Medium Enterprises, Problems of Management in the 21st century Vol.5.5. pp.16-30.

[18] Ujhelyi M. - Kun A. (2016): Szervezeti változásokat kiváltó tényezók empirikus vizsgálata. Taylor: Gazdálkodás- és szervezéstudományi folyóirat: A Virtuális Intézet Közép- Európa Kutatására Közleményei. VIII. évf. (2) pp.36-43.

[19] Farkas G. - Imreh Sz. - Keczer G. - Málovics É. (2015): Menedzsment alapok. Szeged: SZTE GTK, elektronikus jegyzet. http://www.jgypk.hu/tamop15e/tananyag html/Menedzsment alapjai/

[20] Porter, M. E. (2006): Versenystratégia, Budapest, Akadémia kiadó, ISBN 978963 0583497, p. 31

[21] Sebestyén Z. - Pádár K. - Pataki B. (2012): A projektek és a változtatások szerepelméleteinek összehasonlítása in: Vezetéstudomány XLII. évfolyam 2012/3.szám, p.30- 31 .

[22] Kaplan R.S. - Norton D.P. (1996a): Translating strategy into action the Balanced Scorecard, USA, Harvard Business School, Boston, Massachusetts,p.7-9.

[23] Kaplan R.S. - Norton D. P. (1996b): Using the Balance Scorecard as a Strategic Managment System in Focusing your organization on strategy - with the Balanced Scorecard, 2nd edition, p. 37-39

http://www.paca-online.org/cop/docs/Kaplan+Norton_Balanced_Scorecard__3_articles.pdf\#page $=36$

[24] Juhász Cs. (2016): Szervezeti tudásmegosztás. Gradus Vol 3, No 1, pp.404-409. 